\title{
PENGARUH AKTIVITAS PASAR TERHADAP KARAKTER LALU LINTAS: STUDI KASUS AREA PASAR GEDE SURAKARTA
}

\author{
Muhammad Birawan Aulia Abshar'1, Soedwiwahjono1, Kuswanto Nurhadi² \\ 1 Program Studi Perencanaan Wilayah dan Kota, Fakultas Teknik, Universitas Sebelas Maret \\ 2 Program Studi Teknik Sipil, Fakultas Teknik, Universitas Sebelas Maret
}

\begin{abstract}
Abstrak
Aktivitas pasar mempengaruhi kondisi lalu lintas di sekitarnya. Karakteristik lalu lintas pada ruas jalan dan lingkungan yang pada kasus penelitian ini adalah interaksi pengendara dari pelaku aktivitas Pasar Gede yang kemudian mempengaruhi kondisi lalu lintas. Suatu karakteristik lalu lintas dipengaruhi oleh aktivitas yang ada pada ruas jalan dan lingkungan tersebut. Dengan letak pasar yang berada di pusat kota, Pasar Gede menjadi pusat kegiatan bagi pelaku aktivitas yang memunculkan sirkulasi kendaraan antara pengunjung pasar dengan pengguna jalan. Adanya sebuah aktivitas pasar pada ruas jalan tentunya memiliki dampak terhadap karakteristik lalu lintas di sekitarnya. Aktivitas Pasar Gede diidentifikasi berdasarkan variabel yang telah dijadikan indikator yaitu pelaku aktivitas (orang) yang bersirkulasi masuk pasar serta hambatan samping. Sementara, karakteristik lalu lintas pada kawasan Pasar Gede diidentifikasi berdasarkan variabel yang telah dijadikan indikator yaitu kapasitas dan volume lalu lintas. Penelitian ini merupakan penelitian kuantitatif dengan menggunakan pendekatan deduktif serta teknik analisis regresi linier, kapasitas, derajat kejenuhan, dan deskriptif berdasarkan skoring. Data dalam penelitian ini diperoleh melalui observasi. Hasil analisis regresi menunjukkan pengaruh terbesar antara volume pengunjung pasar dengan volume lalu lintas pada kawasan Pasar Gede berada pada JI. Urip Sumoharjo. Sementara hasil skoring menunjukan bahwa pengaruh aktivitas Pasar Gede berdampak pada karakteristik lalu lintas sekitarnya yang menjadi fluktuatif seperti: arus lalu lintas stabil dengan derajat kejenuhan sebesar 0,55 di Jl. Kapten Mulyadi, arus lalu lintas mendekati tidak stabil dengan derajat kejenuhan jalan sebesar 0,73 di Jl. Utara Pasar, arus lalu lintas berhenti, dan macet (mencapai titik jenuh jalan) dengan derajat kejenuhan 1,09 di Jl. RE Martadinata.
\end{abstract}

Kata kunci: aktivitas pasar, karakteristik lalu lintas, titik jenuh jalan

\begin{abstract}
Market activity affects traffic conditions. This study investigates the iinfluence of motorists from Pasar Gede to traffic conditions or character around Pasar Gede in Surakarta.As a major traditional market in Surakarta, Pasar Gede has been the center of activity of people that generates a dense circulation of vehicles between market visitors and road users... Traffic characteristics in Pasar Gede area are identified based on two variables, which are traffic capacity and volume. This research applies quantitative study with linear regression analysis techniques, capacity, degree of saturation, and descriptive based on scoring. Data is collected by doing field observation. Regression analysis results showed the greatest influence between the volume of market visitors with the volume of traffic in Pasar Gede area located on JI Urip Sumoharjo. While the scoring results show that the influence of Pasar Gede's activities has an impact on the characteristics of the surrounding traffic, making the traffic fluctuate, from a stable traffic flow with a degree of saturation of 0.55 on Jl Kapten Mulyadi, to unstable, with a degree of road saturation of 0.73 on JI Utara Pasar, traffic flow stops, and is stuck (reaching the road saturation point) with a degree of saturation of 1.09 on JI RE Martadinata.
\end{abstract}

Keywords: market activity; road saturation point; traffic characteristics

\section{PENDAHULUAN}

Aktivitas pasar merupakan bagian dari aktivitas perdagangan jasa berbelanja. Aktivitas sendiri adalah kegiatan yang dilakukan seseorang dengan berbagai macam tujuan, ada aktivitas bekerja, berbelanja, sekolah, rekreasi, dll. Aktivitas kegiatan yang melibatkan manusia dengan kendaraan tentu memiliki dampak pada jaringan jalan dan juga lalu lintas. Setiap tata guna lahan atau sistem kegiataan dengan kegunaan tertentu akan membangkitkan pergerakan serta akan menarik 
pergerakan pula dalam proses pemenuhan kebutuhan (Tamin,2000). Terkait dengan aktivitas pasar, tata guna lahan yang memiliki pengaruh cukup besar terhadap pergerakan lalu lintas adalah perdagangan (Tamin,2000).

Aktivitas pasar khususnya Pasar Gede tentu memiliki kaitan dengan pergerakan, pergerakan memiliki kaitan dengan pengendara, dan karenanya aktivitas Pasar Gede memiliki pengaruh terhadap keadaan lalu lintas di sekitarnya. Keadaan lalu lintas ini yang sering dikaji dalam dunia perencanaan transportasi dikenal dengan karakteristik lalu lintas. Karakteristik lalu lintas digambarkan secara kuantitatif dengan menggunakan parameter tertentu. Parameter ini diukur dengan menganalisis, dan pelakunya (Oglesby, C.h. \& Hicks.R.G. 1998).

Aktivitas Pasar Gede dilihat kondisi empirisnya, menjadi aktivitas pasar di Kota Surakarta yang memiliki aktivitas paling ramai. Selain itu, Pasar Gede juga dikenal sebagai pasar tertua dan terlengkap di Kota Surakarta. Tentu dengan tingginya aktivitas pada Pasar Gede memiliki pengaruh atau dampak yang berimplikasi pada lalu lintas di sekitarnya. Sedangkan jika melihat realita dunia lalu lintas, sering dijumpai keadaan dimana terjadi kepadatan, penumpukan kendaraan, kemacetan atau overload services yang pasti juga dipicu oleh hal hal tertentu (Aliyah, 2015)

Terkait hal di atas, melihat kondisi lapangan di Kawasan Pasar Gede ketika akhir pekan tepatnya hari dimana biasanya masyarakat berlibur dan melakukan belanja kebutuhan sehari-hari terlihat keadaan lalu lintas pada kawasan mengalami kepadatan, dan seringkali terjadi kemacetan. Penelitian ini bertujuan untuk meneliti bagaimana pengaruh aktivitas Pasar Gede terhadap karakteristik lalu lintas di sekitarnya. Karena hal ini sangatlah penting untuk menjadi kajian dalam mengatasi masalah masalah yang ada dalam dunia perencanaan, maupun manajemen rekayasa lalu lintas.

\section{KAJIAN LITERATUR}

\subsection{AKTIVITAS PASAR}

Aktivitas pasar adalah aktivitas manusia yang melakukan kegiatan di dalam pasar, kegiatan yang dilakukan antara lain transaksi jual beli. Pasar adalah tempat aktivitas penjual pembeli bertemu untuk mengadakan tukar menukar (Belshaw, 1981). Indikasi adanya aktivitas pasar ditandai dengan adanya sirkulasi pengunjung pada pasar (Kumoro, 2009). Aktivitas pasar biasanya ditunjang dengan kelengkapan fasilitas lainnya yaitu tempat parkir, apabila pasar tidak memiliki tempat parkir maka yang terjadi adalah pelaku kegiatan pasar akan memarkirkan kendaraan di badan atau bahu jalan sehingga ruang jalan akan menjadi tempat parkir, yang berarti mengurangi lebar efektif jalan dan menjadikanya hambatan samping jalan karena aktivitas pasar hingga pada akhirnya berpengaruh pada kapasitas ruang yang bersangkutan. Akibatnya selanjutnya adalah kemacetan lalu lintas (Warpani, 2002). Hambatan samping dari aktivitas pasar menimbulkan konflik dan berpengaruh terhadap pergerakan arus lalu lintas serta menurunkan fungsi kinerja jalan (MKJI, 1997).

\subsection{KARAKTERISTIK LALU LINTAS}

Karakteristik lalu lintas adalah bentuk arus lalu lintas dari interaksi antara individu pengendara pada ruas jalan dan lingkungannya. Dari setiap pengendara memiliki kemampuan individu mengemudi dan juga persepsi yang berbeda-beda sehingga menghasilkan karakteristik arus lalu lintas yang berbeda pula pada setiap tempat. Karakteristik lalu lintas dilihat dari volume (Oglesby, C.h \& Hicks. R.G, 1998) dan kapasitas jalan (MKJI 1997). Volume yang dimaksud adalah volume lalu lintas pada kawasan dan kapasitas yang dimaksud adalah kemampuan jalan dalam menampung kendaraan dalam satuan waktu.

\subsection{PENGARUH AKTIVITAS PASAR TERHADAP KARAKTERISTIK LALU LINTAS}

Pengaruh aktivitas pasar terhadap karakteristik lalu lintas dilihat dengan cara yang pertama menganalisa variabel aktivitas pasar yaitu jumlah manusia $(X)$ dengan variabel karakteristik lalu lintas yaitu volume kendaraan $(Y)$. Kedua variabel ini di analisa melalui analisis regresi linier sederhana (Gujarati, 2009). Selain dilihat dari hubungan pengaruh dua variabel, pengaruh aktivitas pasar dapat dilihat dari dampak aktivitas pasar terhadap hambatan samping aktivitas pasar sepanjang jalan yang membuat para pelaku aktivitas memarkirkan kendaraan di bahu dan badan jalan. Dengan menggunakan cara perhitungan dari MKJI (1997) dapat diketahui bagaimana aktivitas pasar yang tinggi hambatan sampingnya dapat mengurangi kapasitas jalan, dan membuat volume lalu lintas semakin padat dan menyebabkan penumpukkan kendaraan yang lewat. 
Puncaknya karakteristik lalu lintas di sekitarnya dapat dilihat dari indeks tingkat pelayanan jalan, kemudian dampak dari aktivitas pasar dilihat dari volume lalu lintas dan hambatan samping, sehingga memperlihatkan besarnya kejenuhan jalan karena aktivitas ini. Pengaruh akan terlihat secara gamblang dengan dilakukanya beberapa analisis.

\section{METODE PENELITIAN}

Pendekatan yang digunakan dalam penelitian ini yaitu pendekatan deduktif, pendekatan deduktif adalah pendekatan dengan melihat fenomena empiris kemudian dikaitkan teori. Pendekatan deduktif dilakukan peneliti dengan tahapan awal melihat fenomena yang terjadi pada kawasan Pasar Gede yang memperlihatkan kepadatan pada waktu tertentu sehingga menimbulkan isu permasalahan yang berimplikasi pada lalu lintasnya. Sebagai mana fenomena tersebut terlihat, kemudian eksplorasi teori terkait Aktivitas Pasar Gede dan keterkaitanya terhadap karakteristik lalu lintas di sekitarnya. Kawasan yang menjadi penelitian terdiri dari empat ruas jalan yaitu JI. Urip Sumoharjo, JI. RE Martadinata, Jl. Kapten Mulyadi, dan JI. Utara Pasar (lihat Gambar 1). Keempat jalan inilah yang mengelilingi Pasar Gede dan membentuk sebuah kawasan yang pada setiap jalannya mengalami kepadatan pada saat tertentu pada awal pengamatan sekilas dilakukan.

Penelitian ini menggunakan data primer melalui observasi lapangan. Data yang diperoleh dan digunakan dalam penelitian ini adalah data sirkulasi orang masuk pasar, kemudian data volume lalu lintas, kemudian data geometri jalan dan hambatan samping. Pengambilan data dilakukan berhari-hari berturut-turut dari jumat, sabtu, minggu, dan senin dari pagi hari hingga sore hari. Data-data ini wujudnya kuantitatif, berdasarkan variabel yang bisa dihitung dalam wujud angka terukur. Dengan menggunakan analisis regresi linier dan derajat kejenuhan untuk melihat pengaruh antar dua variabel berbeda, kemudian keduanya diberikan skoring untuk melihat bobot pengaruh yang dijelaskan melalui narasi deskriptif.

Substansi yang menjadi pokok pembahasan pada penelitian adalah pengaruh aktivitas Pasar Gede terhadap karakteristik lalu lintas di sekitarnya. Nantinya bentuk pengaruh terlihat melalui $r$ square dalam analisis regresi linier antara variabel $(x)$ Pengunjung Pasar Gede dengan variabel (y) volume lalu lintas. Selain itu, pengaruh juga terlihat melalui analisis derajat kejenuhan karena memperlihatkan dampak aktivitas Pasar Gede terhadap kejenuhan jalan di sekitarnya.

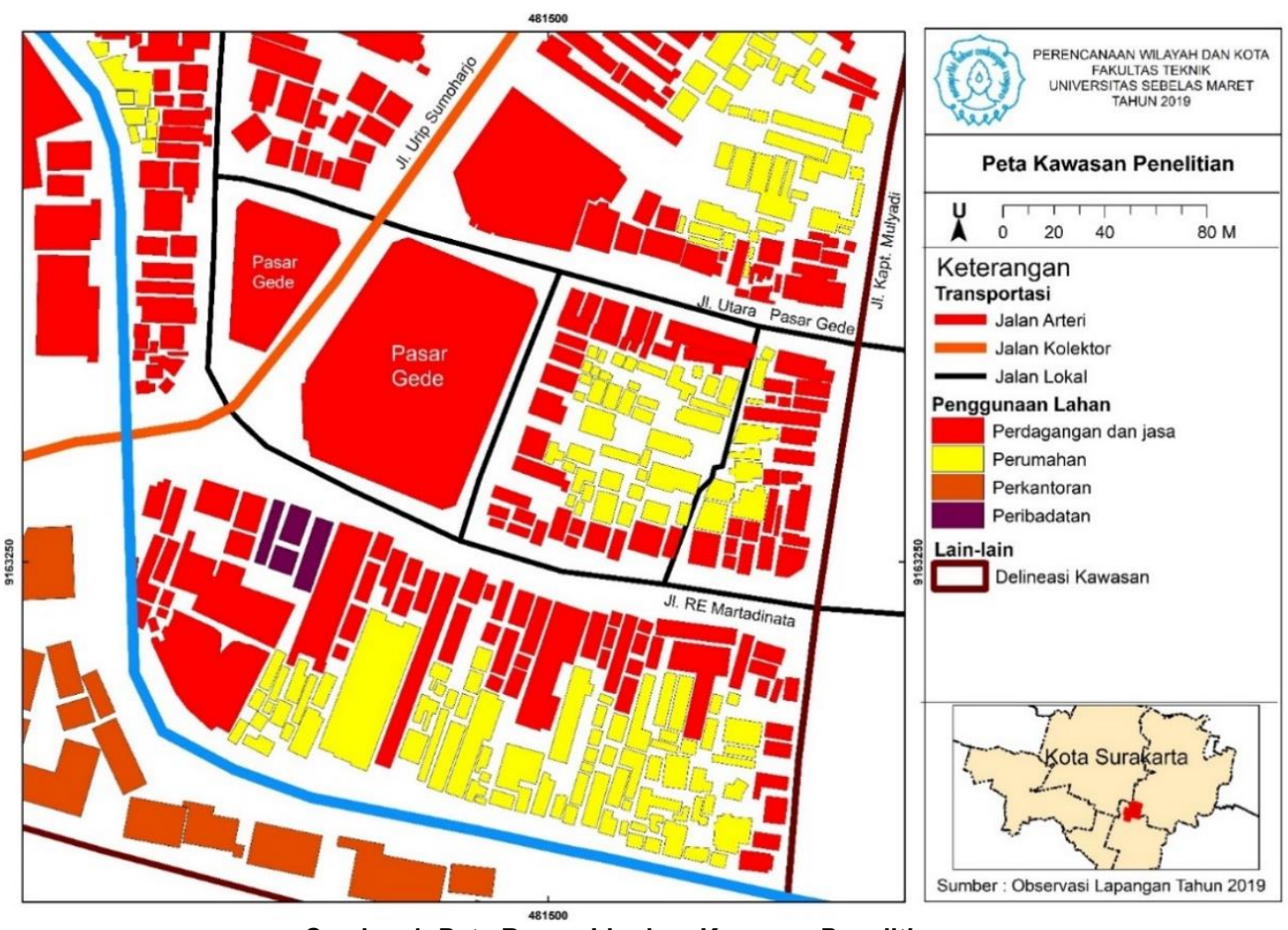

Gambar 1. Peta Ruang Lingkup Kawasan Penelitian 
Tabel 1. Variabel dan Indikator

\begin{tabular}{|c|c|c|c|}
\hline Variabel & Sub Variabel & Indikator & Kriteria \\
\hline \multirow{3}{*}{ Aktivitas Pasar } & Pengunjung Pasar & $\begin{array}{l}\text { Jumlah orang memasuki } \\
\text { pasar pagi hingga sore hari }\end{array}$ & $\begin{array}{c}\text { Terjadinya sirkulasi pengunjung } \\
\text { dengan jumlah angka tertentu } \\
\text { setiap harinya }\end{array}$ \\
\hline & $\begin{array}{c}\text { Hambatan Samping } \\
\text { Aktivitas Pasar }\end{array}$ & $\begin{array}{c}\text { Ukuran jalan di setiap sisi } \\
\text { pasar, besar hambatan } \\
\text { samping }\end{array}$ & $\begin{array}{c}\text { Teridentifikasi jumlah angka } \\
\text { hambatan samping pasar karena } \\
\text { digunakan sebagai lahan parkir }\end{array}$ \\
\hline & Volume Lalu Lintas & $\begin{array}{c}\text { Jumlah kendaraan yang } \\
\text { melintasi kawasan pasar } \\
\text { dengan jumlah tertentu setiap } \\
\text { harinya }\end{array}$ & $\begin{array}{c}\text { Terhitung jumlah volume } \\
\text { kendaraan yang melintasi kawasan } \\
\text { penelitian }\end{array}$ \\
\hline \multirow{3}{*}{$\begin{array}{l}\text { Karakteristik Lalu } \\
\text { Lintas }\end{array}$} & & Kanasitas jalan nada & Terhitung besarnya kapasitas \\
\hline & Kapasitas Eksisting & $\begin{array}{c}\text { kawasan Pasar Gede setiap } \\
\text { harinya }\end{array}$ & $\begin{array}{c}\text { jalan, hal ini memiliki kaitan } \\
\text { terhadap kejenuhan jalan dan } \\
\text { pelayanan jalan }\end{array}$ \\
\hline & $\begin{array}{l}\text { Tingkat pelayanan } \\
\text { jalan }\end{array}$ & $\begin{array}{c}\text { Kinerja jalan di samping } \\
\text { aktivitas pasar }\end{array}$ & $\begin{array}{l}\text { Tingkat pelayanan jalan yang } \\
\text { berdampak pada lalu lintas }\end{array}$ \\
\hline
\end{tabular}

Berdasarkan sintesa dari kajian teori dapat dirumuskan variabel dari penelitian ini adalah aktivitas pasar dengan sub variabel pengunjung pasar dan hambatan samping aktivitas pasar, serta karakteristik lalu lintas dengan sub variabel volume lalu lintas, kapasitas eksisting, dan tingkat pelayanan jalan (lihat Tabel 1). Pembobotan nilai SPSS regresi liner sederhana dapat dilihat pada Tabel 2. Adapun indikator skoring derajat kejenuhan dapat dilihat pada Tabel 3.

Tabel 2. Pembobotan Nilai SPSS Regresi Linier Sederhana

\begin{tabular}{cc}
$\boldsymbol{R}$ Square SPSS Regresi Linier & Pembobotan Nilai \\
\hline $0-19 \%$ & 15 \\
$20-44 \%$ & 35 \\
$45-74 \%$ & 65 \\
$75-84 \%$ & 75 \\
$85-94 \%$ & 85 \\
$95-100 \%$ & 100 \\
\hline
\end{tabular}

\section{Rumus Derajat Kejenuhan}

$$
\mathrm{DS}=\mathrm{Q} / \mathrm{C}
$$

DS adalah derajat kejenuhan

$Q$ adalah volume jam puncak yang didapat berdasarkan traffic counting selama pagi-sore hari.

$\mathrm{C}$ adalah kapasitas yang didapat melalui pengukuran geometri, penghitungan kapasitas dan hambatan samping aktivitas pasar, adapun rumusnya antara lain:

$$
\text { C }=\text { Co } \times \text { Fcw } \times \text { Fcsp } \times \text { FCsf } \times \text { FCcs }(\mathrm{smp} / \text { jam) }
$$

\section{Keterangan :}

C : Kapasitas,

Co : Kapasitas dasar (smp/jam),

FCw : Faktor penyesuaian lebar jalur lalu lintas,

FCsp : Faktor penyesuaian pemisahan arah,

FCsf : Faktor hambatan samping.

FCcs : Faktor penyesuaian ukuran kota. 
Tabel 3. Indikator Skoring Derajat Kejenuhan

\begin{tabular}{cccc}
\hline Tingkat Pelayanan & Rasio $(\mathbf{V} / \mathbf{C})$ & Karakteristik & Pembobotan Nilai \\
\hline A & $0,00-0,19$ & Arus lancar, volume rendah, kecepatan tinggi & 15 \\
B & $0,20-0,44$ & Arus stabil, kecepatan terbatas, volume sesuai untuk kota & 35 \\
C & $0,45-0,74$ & Arus stabil, kecepatan dipengaruhi oleh lalu lintas, volume sesuai & 50 \\
& & untuk jalan kota & 75 \\
D & $0,75-0,84$ & Mendekati arus tidak stabil, kecepatan rendah & 85 \\
E & $0,85-1,00$ & Arus tidak stabil, kecepatan rendah, volume padat atau mendekati & kapasitas \\
F & $>1$ & Arus yang terhambat, kecepatan rendah, volume di atas kapasitas & 100 \\
\hline
\end{tabular}

Sumber: MKJI 1997

Teknik analisis yang digunakan dalam penelitian ini adalah analisis deskriptif kuantitatif yang didukung melalui analisis SPSS, dan analisis derajat kejenuhan. Analisis skoring dari kedua analisis dilakukan oleh peneliti untuk memperoleh penjelasan secara deskriptif yang seimbang dari hasil identifikasi dari masing-masing variabel.

\section{HASIL DAN PEMBAHASAN}

Berdasarkan hasil analisis, dalam hal ini akan dijabarkan mengenai pembahasan dari hasil analisis skoring tiap varibel. Berikut ini merupakan penjabaran dari hasil analisis:

\subsection{PENGARUH AKTIVITAS PASAR GEDE TERHADAP KARAKTERISTIK LALU LINTAS BERDASARAN VOLUME PENGUNJUNG PASAR DAN VOLUME LALU LINTAS (REGRESI LINIER SEDERHANA)}

Berdasasrkan hasil skoring, variabel yang dipakai antara volume pengunjung pasar dengan volume lalu lintas memiliki pengaruh yang tidak terlalu tinggi setiap harinya. Hanya ada satu hari volume pengunjung pasar mempengaruhi volume lalu lintas kawasan dengan persentase yang tinggi yaitu pada hari Minggu di Jl. Urip Sumoharjo ke arah selatan dengan nilai pengaruh sebesar $61,2 \%$. Selain hari Minggu tidak ada pengaruh yang tinggi (melebihi $50 \%$ ) antara volume pengunjung pasar terhadap volume lalu lintas kawasan di sekitar pasar.

Jadi jika melihat pengaruh aktivitas Pasar Gede terhadap karakteristik lalu lintas berdasarkan volume pengunjung pasar dengan volume lalu lintas yang diteliti secara bersamaan dari pagi hingga sore hari setiap harinya terlihat pengaruh yang signifikan hanya pada satu hari saja. Fenomena ini menunjukan bahwa tingkat pengaruh dari pengunjung pasar tidak terlalu besar terhadap kondisi lalu lintas pada kawasan Pasar Gede 

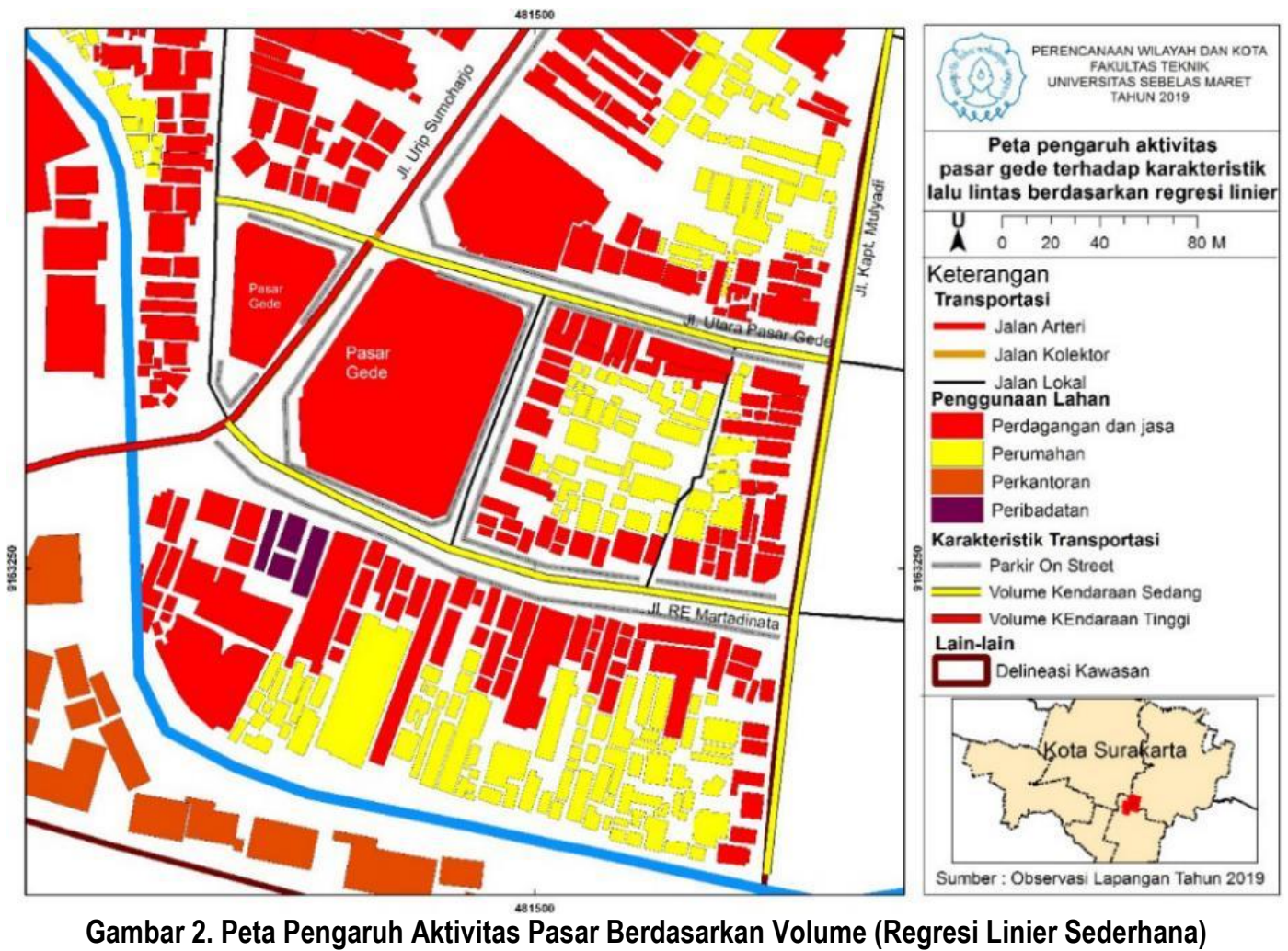

\subsection{PENGARUH AKTIVITAS PASAR GEDE TERHADAP KARAKTERISTIK LALU LINTAS BERDASARKAN DAMPAK HAMBATAN SAMPING AKTIVITAS PASAR TERHADAP KAPASITAS JALAN}

Hambatan samping adalah wujud dari aktivitas pasar yang tinggi namun tidak iringi dengan ketersediaan tempat parkir dengan sistem offstreet parking sehingga pelaku aktivitas pasar melakukan parkir di sisi jalan yang berakibat pada pergerakan arus lalu lintas serta menurunkan fungsi kinerja jalan (MKJI,1997). Fungsi kinerja jaringan jalan menurun karena hambatan samping menyita lebar jalan sehingga daya tampung arus kendaraan yang lewat menjadi berkurang akhirnya kapasitas ruas jalan menjadi turun (Tamin, 2000). Aktivitas pasar yang menimbulkan hambatan samping ini semakin menimbulkan masalah apabila arus lalu lintas pada saat jam puncak terjadi, hambatan samping (side friction) sangat berpengaruh terhadap kapasitas eksisting yang akhirnya menimbulkan kemacetan. Besarnya faktor hambatan samping jalan dengan dan tanpa aktivitas Pasar gede dapat dilihat pada Tabel 4 dan Tabel 5.

Tabel 4. Besarnya Faktor Hambatan Samping Jalan Pada Kawasan Pasar Gede

$\begin{array}{lc}\text { Nama Jalan } & \text { Besar Hambatan Samping } \\ \text { JI. Urip Sumoharjo } & 0,91 \\ \text { Jl. RE Martadinata } & 0,73 \\ \text { JI Utara Pasar } & 0,91 \\ \text { JI Kapten Mulyadi } & 0,91\end{array}$

Tabel 5. Besarnya Faktor Hambatan Samping Jalan Tanpa Aktivitas Pasar Gede

$\begin{array}{lc}\text { Nama Jalan } & \text { Besar Hambatan Samping } \\ \text { Jl. Urip Sumoharjo } & 0,98 \\ \text { Jl. RE Martadinata } & 0,89 \\ \text { JI Utara Pasar } & 0,98 \\ \text { Jl Kapten Mulyadi } & 0,98\end{array}$




\subsection{PENGARUH AKTIVITAS PASAR GEDE TERHADAP KARAKTERISTIK LALU LINTAS BERDASARKAN DERAJAT KEJENUHAN JALAN}

Aktivitas Pasar Gede terhadap karakteristik lalu lintas dilihat berdasarkan derajat kejenuhan akan memperlihatkan bagaimana tingkat kejenuhan jalan karena adanya aktivitas Pasar Gede di sisi jalan. Derajat kejenuhan jalan ini dalam proses perhitunganya mencangkup, keterkaitan dengan hambatan samping aktivitas pada sisi jalan, kondisi kapasitas eksisting jalan, dan juga volume lalu lintas saat jam puncak. Ke semua ini nantinya diolah dan dihitung sesuai ketentuan dalam MKJI 1997 sehingga dapat mengetahui derajat kejenuhannya. Semakin kondisi derajat kejenuhan jalan mendekati titik jenuh atau melebihi titik jenuh (>1) maka hal ini memperlihatkan bahwa aktivitas Pasar Gede menyebabkan karakteristik lalu lintas menjadi jenuh, kondisi lalu lintas mengalami kemacetan untuk saat tertentu. Adapun setelah analisis derajat kejenuhan dilakukan, didapatkan sebuah hasil dengan indeks tingkat pelayanan sebagai berikut (lihat Tabel 6).

Tabel 6. Nilai Derajat Kejenuhan Jalan Pada Kawasan Pasar Gede

\begin{tabular}{|c|c|c|c|}
\hline No & Nama Jalan & $\begin{array}{c}\text { Angka Urutan Derajat Kejenuhan Jalan } \\
\text { Tinggi hingga Rendah }\end{array}$ & Nilai Indeks Tingkat Pelayanan Jalan \\
\hline \multicolumn{4}{|c|}{ Hari Jumat } \\
\hline 1 & Jl. RE Martadinata & 0.78 & D \\
\hline 2 & Jl. Utara Pasar & 0.69 & C \\
\hline 3 & Jl. Urip Sumoharjo & 0.62 & C \\
\hline 4 & Jl. Kapten Mulyadi & 0.55 & C \\
\hline \multicolumn{4}{|c|}{ Hari Sabtu } \\
\hline 1 & Jl. Utara Pasar & 0,73 & C \\
\hline 2 & Jl. RE Martadinata & 0,68 & C \\
\hline 3 & Jl. Urip Sumoharjo & 0,61 & C \\
\hline 4 & Jl. Kapten Mulyadi & 0,43 & B \\
\hline \multicolumn{4}{|c|}{ Hari Minggu } \\
\hline 1 & Jl. RE Martadinata & 1,09 & $\mathrm{~F}$ \\
\hline 2 & Jl. Utara Pasar & 0,71 & C \\
\hline 3 & Jl. Kapten Mulyadi & 0,40 & B \\
\hline 4 & Jl. Urip Sumoharjo & 0,39 & $B$ \\
\hline \multicolumn{4}{|c|}{ Hari Senin } \\
\hline 1 & Jl. Urip Sumoharjo & 0,63 & C \\
\hline 2 & Jl. Kapten Mulyadi & 0,61 & C \\
\hline 3 & Jl. RE Martadinata & 0,56 & C \\
\hline 4 & Jl. Utara Pasar & 0,42 & B \\
\hline
\end{tabular}

Aktivitas Pasar Gede menyebabkan angka derajat kejenuhan yang rata-rata mendekati titik kejenuhan jalan, terlihat nilai nya: $D, C, F, C$ dengan angka 0,78; 0,73; 1,09; 0,63. Tentunya angka-angka ini patut mendapatkan perhatian karena dapat berpengaruh terhadap karakteristik lalu lintas pada kawasan Pasar Gede menjadi padat, macet, khususnya pada saat jam puncak.

\subsection{SKORING AKHIR PENGARUH AKTIVITAS PASAR GEDE TERHADAP KARAKTERISTIK LALU LINTAS DISEKITARNYA}

Skoring akhir ini bertujuan untuk melihat dan memberi bobot nilai pengaruh aktivitas Pasar Gede terhadap karakteristik lalu lintas di sekitarnya sesuai dengan berbagai analisis yang telah dilakukan. Pembobotan ini dilakukan dengan nilai yang adil sehingga dapat diambil sebuah keterangan kesimpulan yang komprehensif. Adapun bentuk skoring-nya dapat dilihat pada Tabel 7. 
Tabel 7. Skoring Akhir Pengaruh Aktivitas Pasar Gede Terhadap Karakteristik Lalu Lintas di Sekitarnya

\begin{tabular}{|c|c|c|c|c|c|}
\hline No & Nama Jalan & $\begin{array}{l}\text { Besar Pengaruh } \\
\text { (Berdasar } R \\
\text { Square) }\end{array}$ & $\begin{array}{l}\text { Scoring } R \\
\text { Square }\end{array}$ & $\begin{array}{c}\text { Besar Pengaruh (Berdasarkan } \\
\text { Derajat Kejenuhan) }\end{array}$ & $\begin{array}{l}\text { Scoring Rasio } \\
\text { Derajat Kejenuhan }\end{array}$ \\
\hline \multicolumn{6}{|c|}{ Hari Jumat } \\
\hline 1 & JI. Urip Sumoharjo Ke Utara & $46,4 \%$ & 50 & 0.62 & 50 \\
\hline 2 & Jl. Urip Sumoharjo Ke Selatan & $8,2 \%$ & 15 & 0.62 & 50 \\
\hline 3 & Jl. Utara Pasar & $14,3 \%$ & 15 & 0.69 & 50 \\
\hline 4 & Jl. Kapten Mulyadi Ke Selatan & $1,9 \%$ & 15 & 0.55 & 50 \\
\hline 5 & Jl. Kapten Mulyadi Ke Timur & $10,7 \%$ & 15 & 0,55 & 50 \\
\hline 6 & Jl. RE Martadinata Satu Arah & $1,6 \%$ & 15 & 0,78 & 75 \\
\hline \multicolumn{6}{|c|}{ Hari Sabtu } \\
\hline 1 & Jl. Urip Sumoharjo Ke Utara & $0,3 \%$ & 15 & 0,61 & 50 \\
\hline 2 & Jl. Urip Sumoharjo Ke Selatan & $18,1 \%$ & 15 & 0,61 & 50 \\
\hline 3 & JI. Utara Pasar & $38,7 \%$ & 35 & 0,73 & 50 \\
\hline 4 & Jl. Kapten Mulyadi Ke Selatan & $14,6 \%$ & 15 & 0,43 & 35 \\
\hline 5 & JI. Kapten Mulyadi Ke Timur & $0,3 \%$ & 15 & 0,43 & 35 \\
\hline 6 & Jl. RE Martadinata Satu Arah & $21,4 \%$ & 35 & 0,68 & 50 \\
\hline \multicolumn{6}{|c|}{ Hari Minggu } \\
\hline 1 & Jl. Urip Sumoharjo Ke Utara & $21,4 \%$ & 35 & 0,39 & 35 \\
\hline 2 & JI. Urip Sumoharjo Ke Selatan & $61,2 \%$ & 50 & 0,39 & 35 \\
\hline 3 & JI. Utara Pasar & $59,8 \%$ & 50 & 0,71 & 50 \\
\hline 4 & Jl. Kapten Mulyadi Ke Selatan & $6,2 \%$ & 15 & 0,40 & 35 \\
\hline 5 & Jl. Kapten Mulyadi Ke Timur & $1,9 \%$ & 15 & 0,40 & 35 \\
\hline 6 & Jl. RE Martadinata Satu Arah & $0,1 \%$ & 15 & 1,09 & 100 \\
\hline \multicolumn{6}{|c|}{ Hari Senin } \\
\hline 1 & JI. Urip Sumoharjo Ke Utara & $8 \%$ & 15 & 0,63 & 50 \\
\hline 2 & Jl. Urip Sumoharjo Ke Selatan & $8 \%$ & 15 & 0,63 & 50 \\
\hline 3 & JI. Utara Pasar & $46,8 \%$ & 50 & 0,42 & 35 \\
\hline 4 & Jl. Kapten Mulyadi Ke Selatan & $3 \%$ & 15 & 0,61 & 50 \\
\hline 5 & Jl. Kapten Mulyadi Ke Timur & $1,2 \%$ & 15 & 0,61 & 50 \\
\hline 6 & JI. RE Martadinata Satu Arah & $1,6 \%$ & 15 & 0,56 & 50 \\
\hline
\end{tabular}

Setelah semua analisis diterapkan dan pemberian pembobotan telah dilakukan maka pada akhirnya ditarik sebuah garis penjelasan untuk melihat bagaimana pengaruh aktivitas Pasar Gede terhadap karakteristik lalu lintas di sekitarnya, dari awal penelitian hingga akhir penelitian yang dimaksud dengan karakteristik lalu lintas di sekitarnya adalah karakteristik lalu lintas kawasan Pasar Gede dengan batas barat: JI. Urip Sumoharjo, batas utara: JI. Utara Pasar, batas timur: JI Kapten Mulyadi, batas selatan: JI RE Martadinata (lihat Tabel 8).

Tabel 8. Penjelasan Akhir Pengaruh Aktivitas Pasar Gede Terhadap Karakteristik Lalu Lintas di Sekitarnya

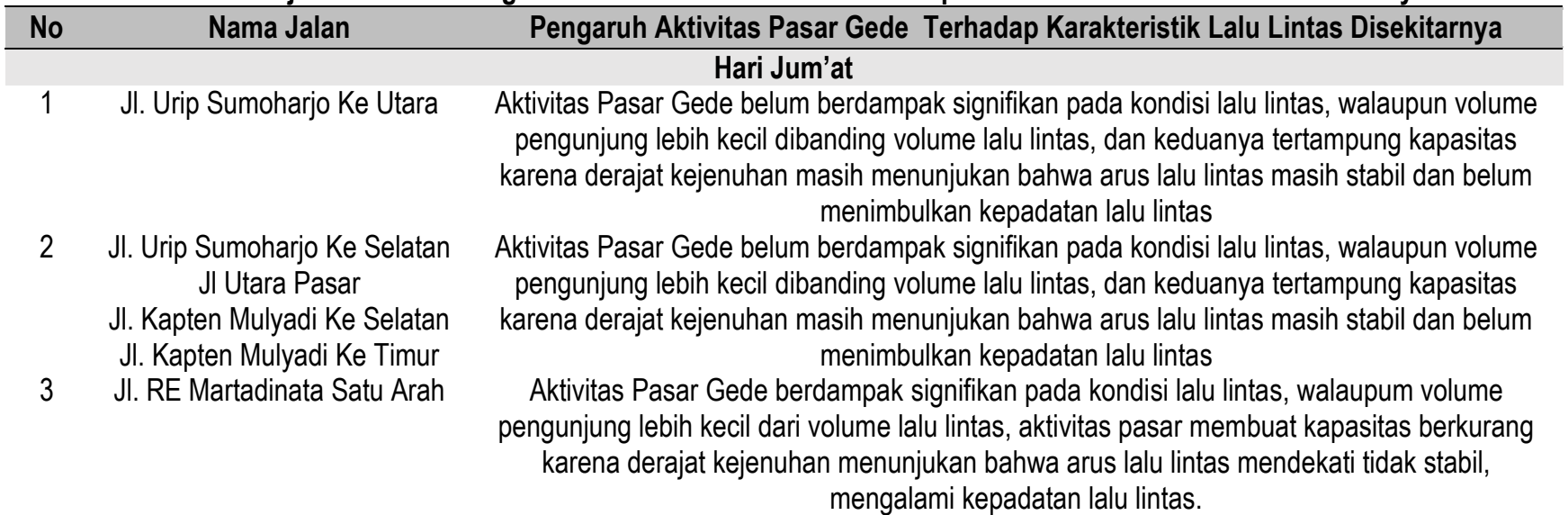




\begin{tabular}{|c|c|c|}
\hline No & Nama Jalan & Pengaruh Aktivitas Pasar Gede Terhadap Karakteristik Lalu Lintas Disekitarnya \\
\hline & & Hari Sabtu \\
\hline \multirow[t]{2}{*}{1} & $\begin{array}{c}\text { JI. Urip Sumoharjo Ke Utara } \\
\text { JI. Urip Sumoharjo Ke Selatan } \\
\text { JI Utara Pasar } \\
\text { JI. Kapten Mulyadi Ke Selatan } \\
\text { Jl.Kapten Mulyadi Ke Timur } \\
\text { Jl. RE Martadinata Satu Arah }\end{array}$ & $\begin{array}{c}\text { Aktivitas Pasar Gede belum berdampak signifikan pada kondisi lalu lintas, walaupun volume } \\
\text { pengunjung dan volume lalu lintas seimbang, keduanya tertampung kapasitas karena derajat } \\
\text { kejenuhan masih menunjukan bahwa arus lalu lintas masih stabil dan belum menimbulkan } \\
\text { kepadatan lalu lintas }\end{array}$ \\
\hline & \multicolumn{2}{|r|}{ Hari Minggu } \\
\hline 1 & Jl. Urip Sumoharjo Ke Utara & $\begin{array}{c}\text { Aktivitas Pasar Gede belum berdampak signifikan pada kondisi lalu lintas, walaupun volume } \\
\text { pengunjung dan volume lalu lintas seimbang, keduanya tertampung kapasitas karena derajat } \\
\text { kejenuhan masih menunjukan bahwa arus lalu lintas masih stabil dan belum menimbulkan } \\
\text { kepadatan lalu lintas }\end{array}$ \\
\hline 2 & Jl. Urip Sumoharjo Ke Selatan & $\begin{array}{c}\text { Aktivitas Pasar Gede belum berdampak signifikan pada kondisi lalu lintas, walaupun volume } \\
\text { pengunjung pasar lebih besar dibanding volume lalu lintas, keduanya tertampung kapasitas } \\
\text { karena derajat kejenuhan masih menunjukan bahwa arus lalu lintas masih stabil dan belum } \\
\text { menimbulkan kepadatan lalu lintas }\end{array}$ \\
\hline 3 & Jl. Utara Pasar & $\begin{array}{c}\text { Aktivitas Pasar Gede belum berdampak signifikan pada kondisi lalu lintas, walaupun volume } \\
\text { pengunjung lebih kecil dibanding volume lalu lintas, dan keduanya tertampung kapasitas } \\
\text { karena derajat kejenuhan masih menunjukan bahwa arus lalu lintas masih stabil dan belum } \\
\text { menimbulkan kepadatan lalu lintas }\end{array}$ \\
\hline 4 & $\begin{array}{l}\text { JI. Kapten Mulyadi Ke Selatan } \\
\text { Jl. Kapten Mulyadi Ke Timur }\end{array}$ & $\begin{array}{c}\text { Aktivitas Pasar Gede belum berdampak signifikan pada kondisi lalu lintas, walaupum volume } \\
\text { pengunjung lebih kecil dari volume lalu lintas, keduanya tertampung kapasitas karena derajat } \\
\text { kejenuhan masih menunjukan bahwa arus lalu lintas masih stabil dan belum menimbulkan } \\
\text { kepadatan lalu lintas }\end{array}$ \\
\hline 5 & JI. RE Martadinata Satu Arah & $\begin{array}{c}\text { Aktivitas Pasar Gede berdampak signifikan pada kondisi lalu lintas, walaupun volume } \\
\text { pengunjung lebih kecil dari volume lalu lintas, aktivitas pasar membuat volume lalu lintas } \\
\text { melebihi kapasitas karena derajat kejenuhan menunjukan bahwa arus lalu lintas berhenti, } \\
\text { dan terjadi kemacetan (melewati titik jenuh }>1 \text { ) }\end{array}$ \\
\hline \multicolumn{3}{|r|}{ Hari Senin } \\
\hline 1 & $\begin{array}{l}\text { Jl. Urip Sumoharjo Ke Utara } \\
\text { JI. Urip Sumoharjo Ke Selatan } \\
\text { Jl. Kapten Mulyadi Ke Selatan } \\
\text { Jl. Ka;pten Mulyadi Ke Timur }\end{array}$ & $\begin{array}{c}\text { Aktivitas Pasar Gede belum berdampak signifikan pada kondisi lalu lintas, walaupun volume } \\
\text { pengunjung lebih kecil dibanding volume lalu lintas, dan keduanya tertampung kapasitas } \\
\text { karena derajat kejenuhan masih menunjukan bahwa arus lalu lintas masih stabil dan belum } \\
\text { menimbulkan kepadatan lalu lintas }\end{array}$ \\
\hline 2 & J. Utara Pasar & $\begin{array}{c}\text { Aktivitas Pasar Gede belum berdampak signifikan pada kondisi lalu lintas, walaupun volume } \\
\text { pengunjung pasar lebih besar dibanding volume lalu lintas, keduanya tertampung kapasitas } \\
\text { karena derajat kejenuhan masih menunjukan bahwa arus lalu lintas masih stabil dan belum } \\
\text { menimbulkan kepadatan lalu lintas }\end{array}$ \\
\hline 3 & Jl. RE Martadinata Satu Arah & $\begin{array}{c}\text { Aktivitas Pasar Gede belum berdampak signifikan pada kondisi lalu lintas, walaupun volume } \\
\text { pengunjung lebih kecil dibanding volume lalu lintas, dan keduanya tertampung kapasitas } \\
\text { karena derajat kejenuhan masih menunjukkan bahwa arus lalu lintas masih stabil dan belum } \\
\text { menimbulkan kepadatan lalu lintas }\end{array}$ \\
\hline
\end{tabular}

Berdasarkan dari hasil skoring di atas menunjukan bahwa secara keseluruhan, pengaruh aktivitas Pasar Gede terhadap karakteristik lalu lintas di sekitarnya ternyata fluktuatif setiap harinya, pada hari hari biasa karakteristik lalu lintas di sekitarnya masih stabil akan tetapi fenomena yang paling menonjol jika dilihat dari skoring derajat kejenuhan jalan, aktivitas Pasar Gede berpengaruh membuat jalan menjadi mendekati atau bahkan melewati titik jenuh pada hari weekend sehingga kondisi lalu lintas pada kawasan menjadi padat pada hari Jumat di JI. RE Martadinata satu arah dan macet pada hari Minggu di Jl. RE Martadinata satu arah. Hal ini salah satunya dikarenakan aktivitas Pasar Gede tidak dilengkapi dengan fasilitas off street parking sehingga pelaku aktivitas Pasar Gede melakukan parkir pada bahu dan badan jalan (on street parking) sehingga mengurangi kapasitas dan ruang jalan pada akhirnya menimbulkan kemacetan.Peta kejenuhan jalan akibat aktivitas Pasar gede dapat dilihat pada Gambar 3. 


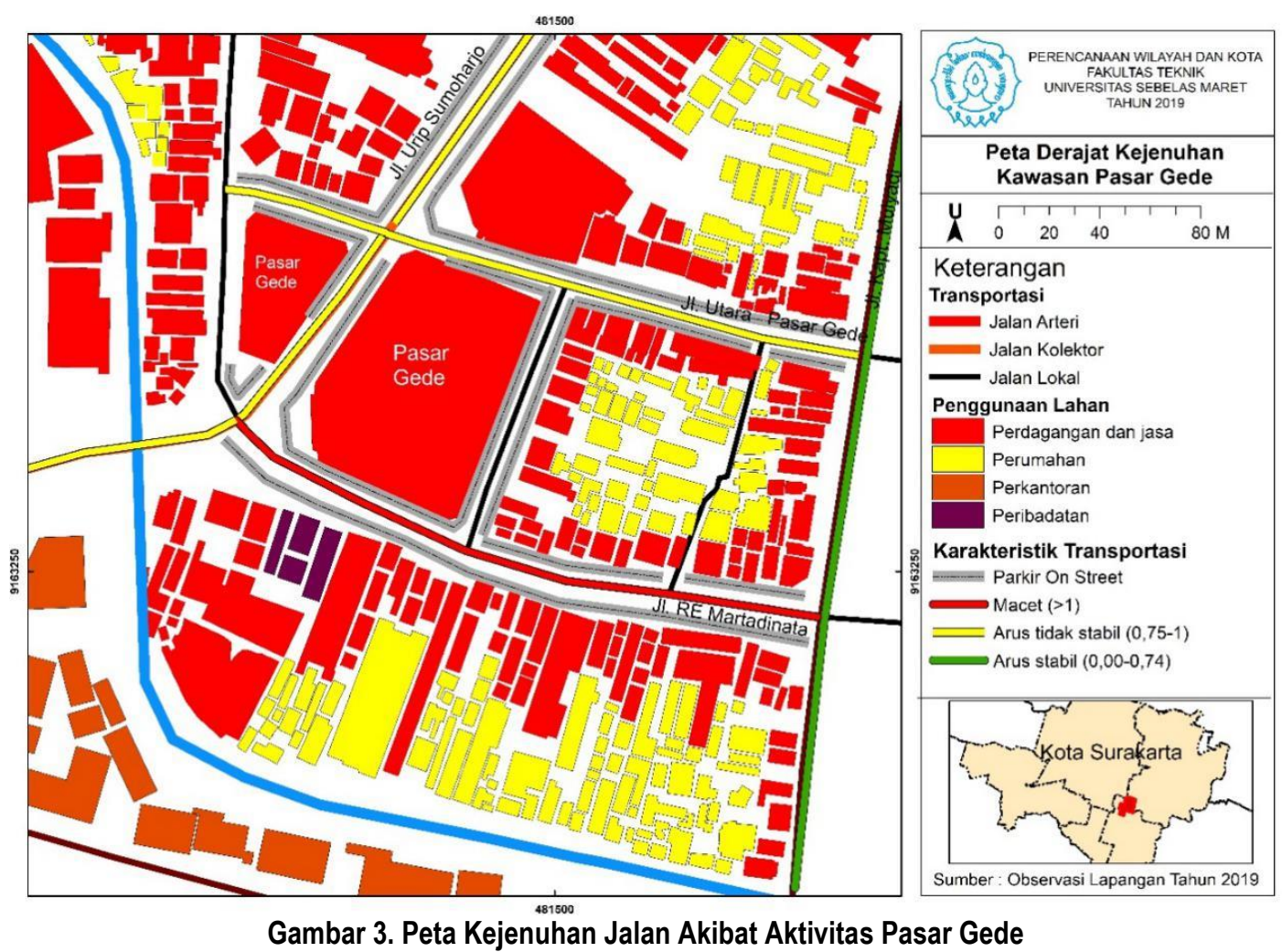

\section{KESIMPULAN}

Berdasarakan hasil penelitian, aktivitas Pasar Gede mempengaruhi karakteristik lalu lintas di sekitarnya bentuk pengaruhnya pun berbeda-berbeda, ada yang walaupun volume pelaku aktivitas Pasar Gede jumlahnya besar tetapi volume lalu lintas tidak begitu besar, atau walaupun pelaku aktivitas Pasar Gede jumlahnya kecil namun volume lalu lintas besar. Ada hari dimana aktivitas Pasar Gede masih berdampak stabil pada kondisi lalu lintas, dan juga ada hari dimana aktivitas Pasar Gede berpengaruh kepada kondisi lalu lintas tidak stabil.

Fenomena yang paling menonjol terjadi adalah kemacetan karena pelaku aktivitas pasar menghasilkan hambatan samping jalan yang disebabkan karena tidak adanya offstreet parking pada Pasar Gede sehingga pelaku aktivitas memarkirkan kendaraan di bahu jalan yang pada akhirnya menyebabkan tingkat jenuhan jalan melebihi kapasitas (derajat kejenuhan $>1$ ), akhirnya membuat lalu lintas terhenti dan inilah yang menjadi sumber utama kemacetan terjadi. Ketika fenomena ini terjadi lalu lintas menjadi terhenti, maka dari itu perlu adanya pengambilan kebijakan yang komprehensif.

Kebijakan dan rekomendasi pemerintah, serta peran masyarakat juga dibutuhkan untuk mengurai permasalahan karakteristik lalu lintas yang disebabkan oleh aktivitas Pasar Gede. Kebijakan pemerintah dan rekomendasi yang bisa diberikan seperti ANDALALIN, menejemen rekayasa lalu lintas, dan penataan lahan parkir. Sedangkan peran masyarakat seperti mencoba membiasakan menggunakan transportasi umum dalam memenuhi aktivitas sehari hari khususnya aktivitas berbelanja di Pasar Gede sehingga mengurangi beban dan kapasitas jalan karena pelaku aktivitas Pasar Gede membebani jalan dengan parkir pada bahu jalan Pasar Gede khususnya di JI. RE Martadinata.

\section{DAFTAR PUSTAKA}

Aliyah, I. (2015). Fleksibilitas Ruang dalam Transformasi Budaya di Kawasan Pasar Tradisional Kota Surakarta (Obyek Studi: Pasar Gede Kota Surakarta). Conference on Urban Studies and Development (CoUSD), 101-118. Diakses dari http://eprints.undip.ac.id/49241/1/2.2.Prosiding_Istijabatul.pdf 
Desa-Kota, Vol. 2, No. 2, 2020, 175-185

Belshaw, C. (1998). Tukar Menukar Tradisional dan Pasar Modern. Jakarta: Gramedia.

Direktorat Jenderal Bina Marga, Departemen Pekerjaan Umum (1997), Manual Kapasitas Jalan Indonesia (MKJI 1997). Diakses dari https://docs.google.com/viewer?a=v\&pid=sites\&srcid=ZGVmYXVsdGRvbWFpbnxtYXRIcmlzaXBpbHNlbWVzdGVyNHxneDoyY2V jYmQ2ZWQwYZRINjll

Gujarati, Damodar, N. \& Porter, D. C. (2009). Basic Econometric 5th Edition. New York: McGraw-Hill

Oglesby, C.H. \& Hicks, R.G., (1993). Teknik Jalan Raya, Jilid I, Edisi Keempat. Jakarta: Gramedia

Tamin, O. Z, 2000. Perencanaan dan Permodelan Transportasi. Bandung. Bandung: Penerbit ITB.

Kumoro, A. (2009). Karakter dan Atribut Ruang Publik Pasar Tradisional Kasus Pasar Legi Surakarta, Majalah Ilmiah Teknik, 10(1) 105. Diakses dari http://puslit2.petra.ac.id/ejournal/index.php/gem/article/view/17591

Warpani, P. S. (2002). Pengelolaan Lalu Lintas dan Angkutan Jalan Bandung. Bandung: ITB 